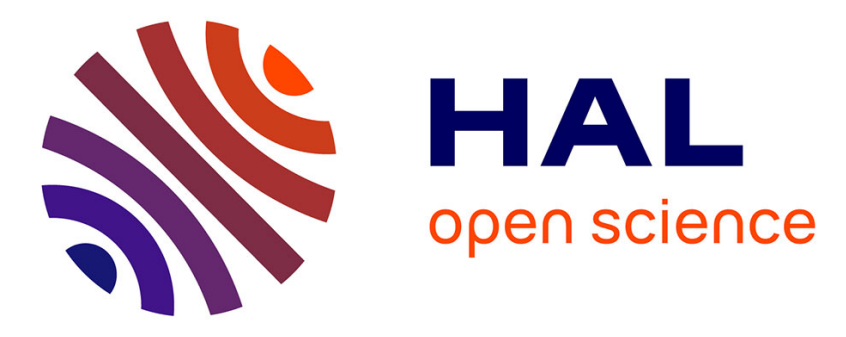

\title{
Surface charge distribution: a key parameter for understanding protein behavior in chromatographic processes
}

Marine Tournois, Stéphane Mathé, Isabelle André, Maria Aurora Fernandez

\section{- To cite this version:}

Marine Tournois, Stéphane Mathé, Isabelle André, Maria Aurora Fernandez. Surface charge distribution: a key parameter for understanding protein behavior in chromatographic processes. Journal of Chromatography A, 2021, 1648, 10.1016/j.chroma.2021.462151 . hal-03269416

\section{HAL Id: hal-03269416 https: / hal.inrae.fr/hal-03269416}

Submitted on 18 Oct 2021

HAL is a multi-disciplinary open access archive for the deposit and dissemination of scientific research documents, whether they are published or not. The documents may come from teaching and research institutions in France or abroad, or from public or private research centers.
L'archive ouverte pluridisciplinaire HAL, est destinée au dépôt et à la diffusion de documents scientifiques de niveau recherche, publiés ou non, émanant des établissements d'enseignement et de recherche français ou étrangers, des laboratoires publics ou privés. 


\title{
Surface charge distribution: a key parameter for understanding protein behavior in chromatographic processes
}

\author{
Marine Tournois, Stéphane Mathé, Isabelle André, Jérémy Esque, María A. Fernández- \\ TBI, Université de Toulouse, CNRS, INRAE, INSA, Toulouse, France
}

articleinfo

Article history:

Received 19 January 2021

Revised 7 April 2021

Accepted 9 April 2021

Available online 16 April 2021

Keywords:

Ion-exchange chromatography

Proteins

Molecular Dynamics

Simultaneous adsorption

Charge distribution abstract

\begin{abstract}
Multi-component adsorption of proteins still requires a better understanding of local phenomena to im- prove the development of predictive models. In this work, all-atom Molecular Dynamics (MD) simula- tions were used to investigate the influence of protein charge distribution on the adsorption capacity. The simultaneous adsorption of $\alpha$-chymotrypsin and lysozyme on a cation exchanger, SP Sepharose FF, was studied through MD simulations and compared to macroscopic isotherm experiments. It appears that the charge distribution is a relevant information to better understand specific phenomena, such as a multilayer adsorption caused by the particular electrostatic profile of $\alpha$-chymotrypsin. Therefore, MD simulations seem to be an interesting way to visualize and highlight these behaviors.
\end{abstract}

of the main drawback of these methods is that it does not pro- vide information on the distribution of charges around the protein surface [12]. Indeed, an

(c) 2021 Elsevier B.V. All rights reserved.

\section{Introduction}

Ion-exchange chromatography is one of the most used process for protein purification [1-3]. However, even though this process is effective for separating simple media, their optimization may re- main difficult when complex media with multiple proteins need to be purified $[4,5]$. While most industrial processes are still based on empirical models, phenomena such as interactions and com-petition between proteins still require a better understanding at molecular level.

The adsorption equilibrium of macromolecules on a porous me- dia is usually described by empirical or semi-empirical models such as Langmuir isotherm [6,7] , the distributed pore model [8] or the Steric Mass Action (SMA) law [9,10] with varying degrees of efficiency $[4,11,12]$. Those models can be useful to predict the salt effect [12] but, meanwhile, can show unreliable results at high pro- tein concentrations for instance [4]. Nowadays, SMA law seems to be one of the most widely used in the specific case of ion- exchange [13] as it considers the displacement of counterions in solution, and is applied to macromolecules such as proteins and accounts for the multipoint nature of the interaction [14] through the value of a characteristic charge. However, it appears that one

\footnotetext{
.Corresponding author.

E-mail address: mafernan@insa-toulouse.fr (M.A. Fernández).
}

heterogenous distribution may affect inter- actions with the environment, in particular with surrounding pro- teins, and then change adsorption behaviors [15] . Therefore, most models used in ion-exchange chromatography may fail to describe multicomponent adsorption based on single-component observa- tions $[4,12]$. A coupling of different models or methods appears to be an interesting strategy, such as Poisson-Boltzmann calculations [16] coupled with stoichiometric models to better predict electro- static effects [17]. Finally, a better understanding of mechanisms involved in multicomponent adsorption, and especially interaction mechanisms between two proteins, could help in the development of predictive models [18] and more generally in the understanding of intermolecular interactions in various processes such as complex coacervation [19].

This preliminary work aims to highlight the potential of Molec-ular Dynamics (MD) simulations as a theoretical method to im- prove knowledge on simultaneous adsorption of two proteins. In particular, the effect of proteins charge distribution on their ad-sorption is analyzed. For this reason, simultaneous retention of $\alpha$-chymotrypsin and lysozyme on a chromatographic surface, SP Sepharose FF, has been studied. First, an experimental study was conducted, involving adsorption isotherm measurements. In paral- lel, MD simulations were performed and then compared to obser- vations drawn from experiments, showing the interest of consid- ering the charge distribution instead of the net charge to better understand ion-exchange behavior.

\section{Materials and Methods}

\subsection{Charge distribution on protein surface}

Protonation states of titrable residues at different $\mathrm{pH}$ were de- termined using 
PROPKA from PDB2PQR web server [20]. The APBS (Adaptive PoissonBoltzmann Solver) tool $[21,22]$ was used to de- termine the charge distribution on protein surfaces and all surface representation figures were obtained using PyMol 1.7 [23] .

\subsection{Protein adsorption}

2.2.1. Multicomponent isotherm experiments $\alpha$-chymotrypsin (C-4129, purity $\geq$ $85 \%$ ) and lysozyme (L-6876, $\geq 90 \%$ ) were purchased from Sigma (St. Louis, MO, USA) and used without prior purification. The salts used for buffer solutions (cit- ric acid, trisodium citrate di-hydrate and sodium chloride) were also obtained from Sigma and were of analytical grade. The ion- exchange resin, SP Sepharose FF, was obtained from GE Healthcare (Uppsala, Sweden).

Multicomponent isotherms were measured using static batch experiments at $\mathrm{T}=20^{\circ} \mathrm{C}, \mathrm{pH}=5(50 \mathrm{mM}$ citrate buffer $)$ and without sodium chloride in solution [24]. The resin was first equili- brated with the buffer solution. A known amount of drained resin, ranging from 0.01 to $0.85 \mathrm{~g}$, was then transferred into several flasks containing $5 \mathrm{~mL}$ of protein solution. The initial concentra- tion of each protein $C_{0, j}$ was set to about $2 \mathrm{~g} / \mathrm{L}$. The sealed flasks were shaken during at least 8 hours in order to reach the equi- librium state. The supernatant was then collected and analyzed. Protein concentrations $C_{i}$ were determined using HPLCSEC (size- exclusion chromatography) according to the protocol described in [24] . Finally, the amount of adsorbed proteins $q_{i}$ was calculated by mass balance, following the equation:

V

$q_{i}=\left(C_{0, i}-C_{i}\right)$

(1)

\section{$V R$}

where $V$ is the protein solution volume, $V_{R}$ the resin volume and $i$ the protein.

\subsubsection{Molecular dynamics simulations}

The system setup for in silico experiments and data analysis methods are the same as described in the previous work [24] . In addition to $\alpha$-chymotrypsin (PDB-ID: 1YPH, resolution 1.34 A), ${ }^{\circ}$ lysozyme was added in the simulation box at the beginning of each simulation. The atomic coordinates of lysozyme were ob- tained from the X-ray structure (PDB-ID: 1AKI) at a resolution of $1.5 \mathrm{~A}$. This protein is composed of one chain, containing 129 residues.

Three initial configurations were studied (Figure SI.1 in Sup- plementary Information) in order to observe the influence of the starting orientation on the adsorption. First, two proteins were in- troduced in the simulation box with two different initial orienta- tions (Figures SI.1.A and B). Both proteins are rotated at $180^{\circ}$ on the y-axis from Configuration 1 (Figure SI.1.A) to obtain Configuration 2 (Figure SI.1.B). Then, four proteins, i.e. two lysozymes and two Qchymotrypsins, were introduced in the simulation box: one protein of each was already adsorbed on the surface at the begin- ning of the simulation and two other proteins were added in the simulation box (Figure SI.1.C). Thus, the effect of adsorbed proteins on the adsorption capacity can be highlighted. MD time length was set to $200 \mathrm{~ns}$ for all simulations.

\section{Results and Discussion}

\subsection{Charge distribution}

Figure 1 represents the charge distribution on protein surfaces from APBS calculations. At pH 5 ( Fig. 1 .A and 1 .B), both proteins are globally positively charged, with a net charge equal to +7 for $\alpha$-chymotrypsin and +10 for lysozyme. Fig. 1 .C and 1 .D show the electrostatic potential at protein surfaces when the $\mathrm{pH}$ is close to the isoelectric point $\mathrm{pI}$, i.e. $\mathrm{pH} 9$ for $\alpha$-chymotrypsin ( $\mathrm{pI}$ $\approx 8.3[25]$ ) and $\mathrm{pH} 11$ for lysozyme ( $\mathrm{pI} \approx 11.3[26]$ ). Thus, the net charges are estimated at +0 for both proteins.

This representation allows to identify and visualize areas on the protein surface that may be involved in the ion-exchange mecha- nism and how the charges are distributed on the surface. At pH 5, $\alpha$-chymotrypsin shows a strongly positively charged region, al- ready identified in previous work [24] to be the predominant ad- sorption patches. Despite some local neutral or negatively charged areas, the net protein charge is positive. As the working $\mathrm{pH}$ gets closer to pI, two distinct and opposite sides with positive and neg- ative charges appear, resulting in a net neutral charge. However, it does not exclude the possibility that the protein may still adsorb to a cationic surface when considering only electrostatic effects. At pH 5, the charge repartition on lysozyme surface seems to be more evenly distributed with positive charges located on the whole surface. At $\mathrm{pH}$ close to $\mathrm{pI}$, neutral, positive and negative charges appear homogeneously without forming two distinct zones. Nev- ertheless, variations such as protein conformational changes may slightly influence the charge distribution on protein surface.

\subsection{Adsorption behavior in multicomponent system}

\subsubsection{Equilibrium isotherms}

The adsorption isotherms, measured at $\mathrm{pH} 5$ in a $100 \mathrm{mmol} / \mathrm{L}$ sodium solution, are presented on Figure 2 . Both single-component ( Figure 2 .A) and multicomponent ( Figure 2 .B) isotherms are shown, in order to highlight the influence of protein competition on the adsorption efficiency.

At high concentrations in lysozyme single-component isotherm ( Figure 2.A), data dispersion increases, which is mainly due to the uncertainties generated by the batch experiments. It appears that the concentration variations during the experiment are equivalent to these uncertainties. In addition, to obtain this data, a very small amount of resin have to be introduced in the tubes, thus increas-ing the uncertainty of this measurement. This isotherm seems to show a Langmuirtype behavior, which is consistent with results from Dismer et al [27] that studied lysozyme in similar conditions (SP Sepharose FF, pH 5). Lysozyme appears to have a stronger affin- ity with the resin than $\alpha$-chymotrypsin regarding the curve shape. This result is consistent with observations made in the previous paragraph 3.1 . Indeed, the global charge of lysozyme is strongly positive and well distributed on the surface, which favors electro- static interactions with the negatively charged resin. As showed in the previous work [24], $\alpha$-chymotrypsin isotherm does not show any atypical behavior in mono-component system.

In multi-component system ( Figure 2 .B), the $\alpha$-chymotrypsin isotherm has the shape of a stepwise curve: when the concen- trations of both proteins in solution are high, i.e. from about $0.04 \mathrm{mmol} / \mathrm{L}$, the shape of the isotherm changes significantly. This type of isotherms can be considered to reflect a multilayer adsorp-tion [28] . However, the abrupt change in the slope of the $\alpha$-chymotrypsin isotherm is only the result of a strong disappear- ance of the protein in solution, because in the experiments only the concentration $C$ is directly measured, $q$ is calculated by mass balance. The assumption made during the calculation of $q$ is that the quantity of protein no longer in solution is retained on the 
a-chymotrypsin

A

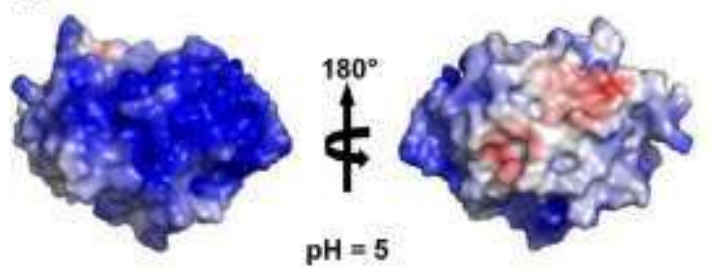

C

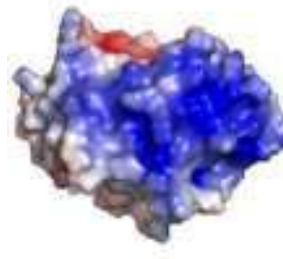

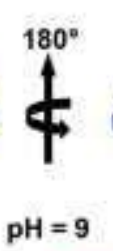

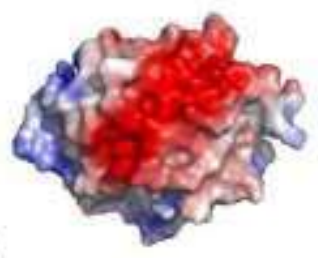

B

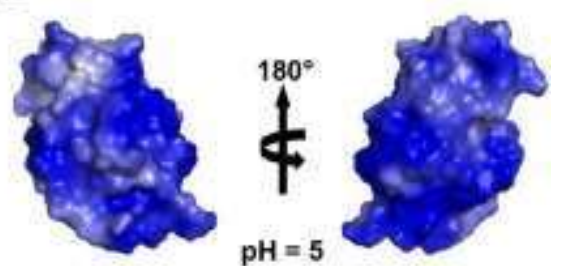

D

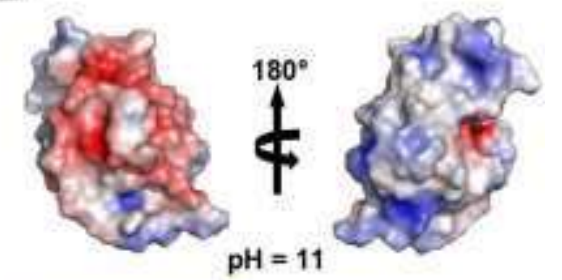

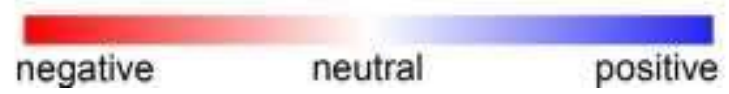

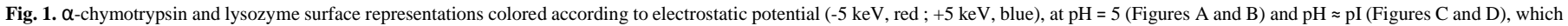

corresponds to $\mathrm{pH} 9$ for $\alpha$-chymotrypsin and 11 for lysozyme.

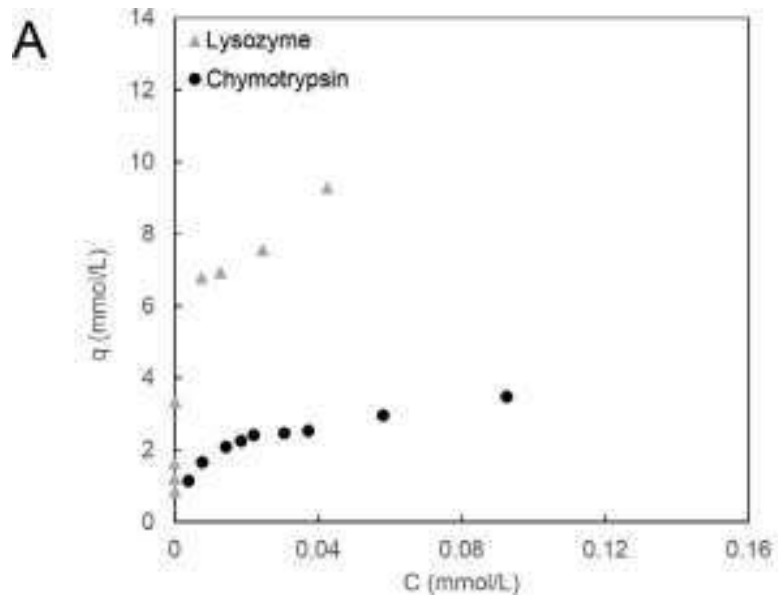

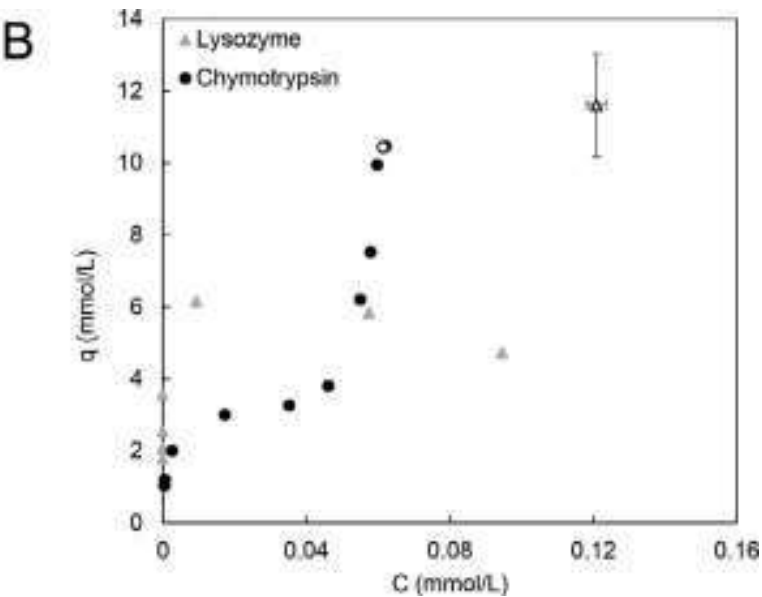

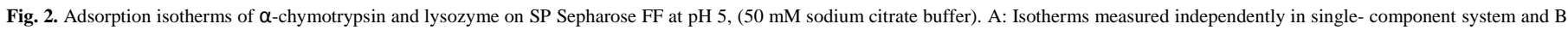

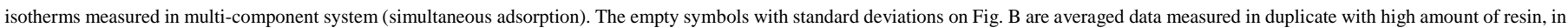
order to confirm isotherm shape.

chromatographic support. Thus, this isotherm can reflect several phenomena such as an interaction between proteins, but also an aggregation or precipitation of $\alpha$ chymotrypsin, which would also explain a decrease in the amount of solubilized protein [28] . In so- lution, no precipitation of the protein was observed, but it is also possible that these phenomena could take place inside the resin, which in this case is difficult to identify experimentally. At this point, two observations are noted:

- The lysozyme seems to have a similar behavior in single and multicomponent systems showing Langmuir-type isotherms. Moreover, this protein shows a stronger affinity with the SP Sepharose FF resin than $\alpha$ chymotrypsin.

- The $\alpha$-chymotrypsin has a different behavior at high concentra- tions (over $0.04 \mathrm{mmol} / \mathrm{L}$ ) in multi-protein system.

\subsubsection{MD simulations}

The adsorption isotherms performed on a multi-protein sys- tem highlighted two distinct situations. The first situation seems to show a weak competition between proteins (concentrations be- low $0.04 \mathrm{mmol} / \mathrm{L}$ ). During the simulation, this case was repre- sented by the configurations with only two proteins in the box. Although there is still enough space on the chromatographic sur- face (around $65 \%$ available) for the two proteins to adsorb indepen- dently, these conditions still represent a competitive situation and may more likely represent a transition between competitive and non-competitive adsorption. In these conditions, four MD simula- tions were run and analyzed. The second situation highlighted by the experiments (protein concentrations higher than $0.04 \mathrm{mmol} / \mathrm{L}$ ) traduces a high competitive adsorption. The configuration contain- ing four proteins in the simulation box was then used to study a higher protein competition. In these conditions, the available sur- face area ratio is around $30 \%$. Three MD simulations were run from this initial configuration.

Some representative results are presented on Figure 3 , show- ing the last frame of each simulation as well as protein-protein and protein-ligands minimum distances over time (complete re- 
A

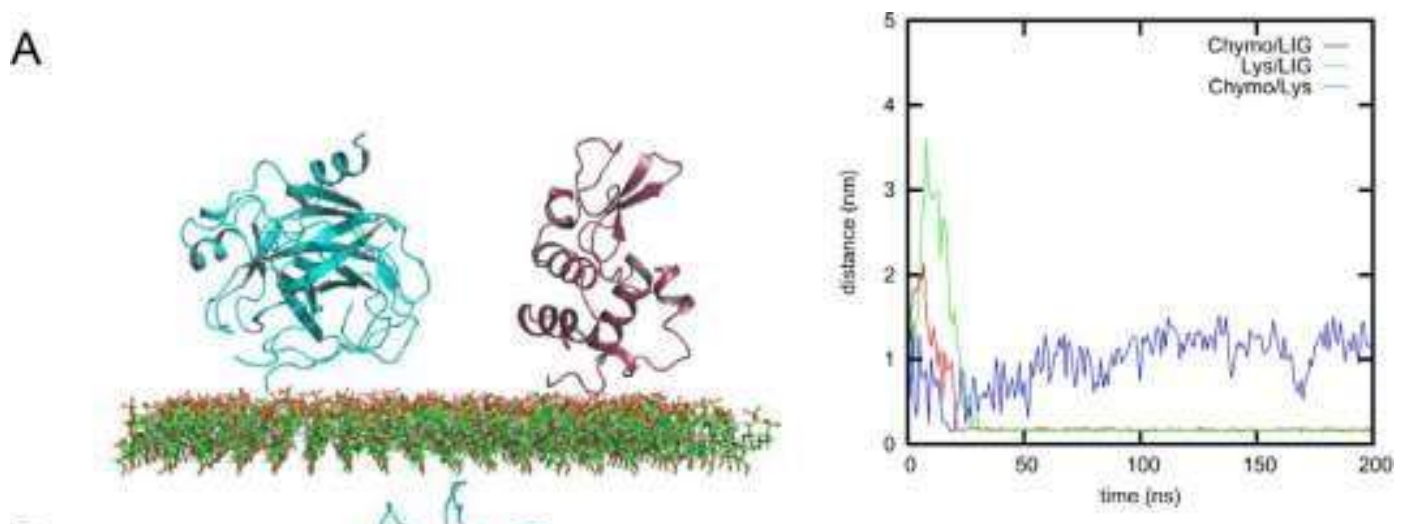

B
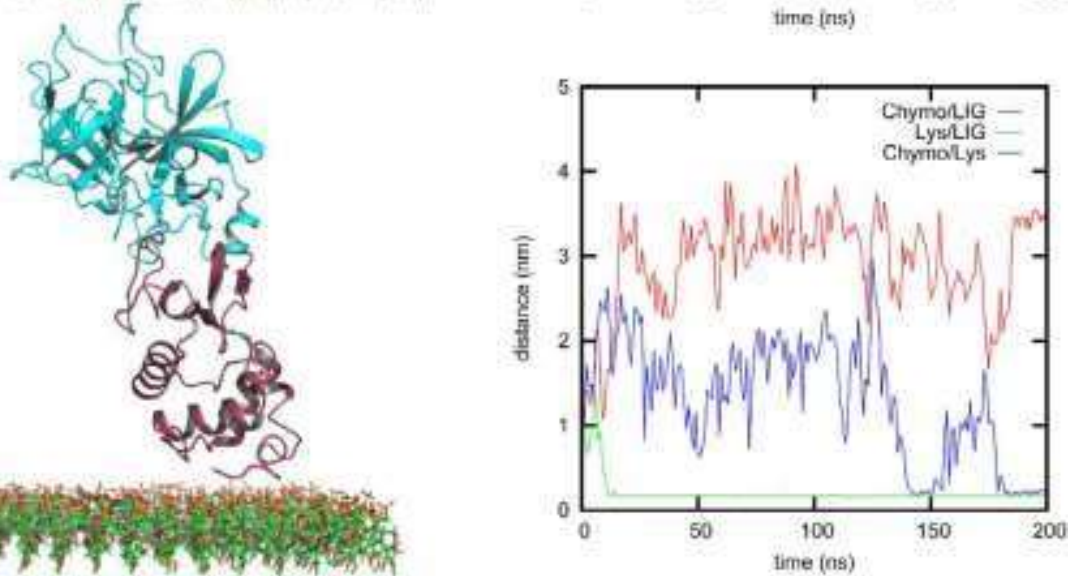

C
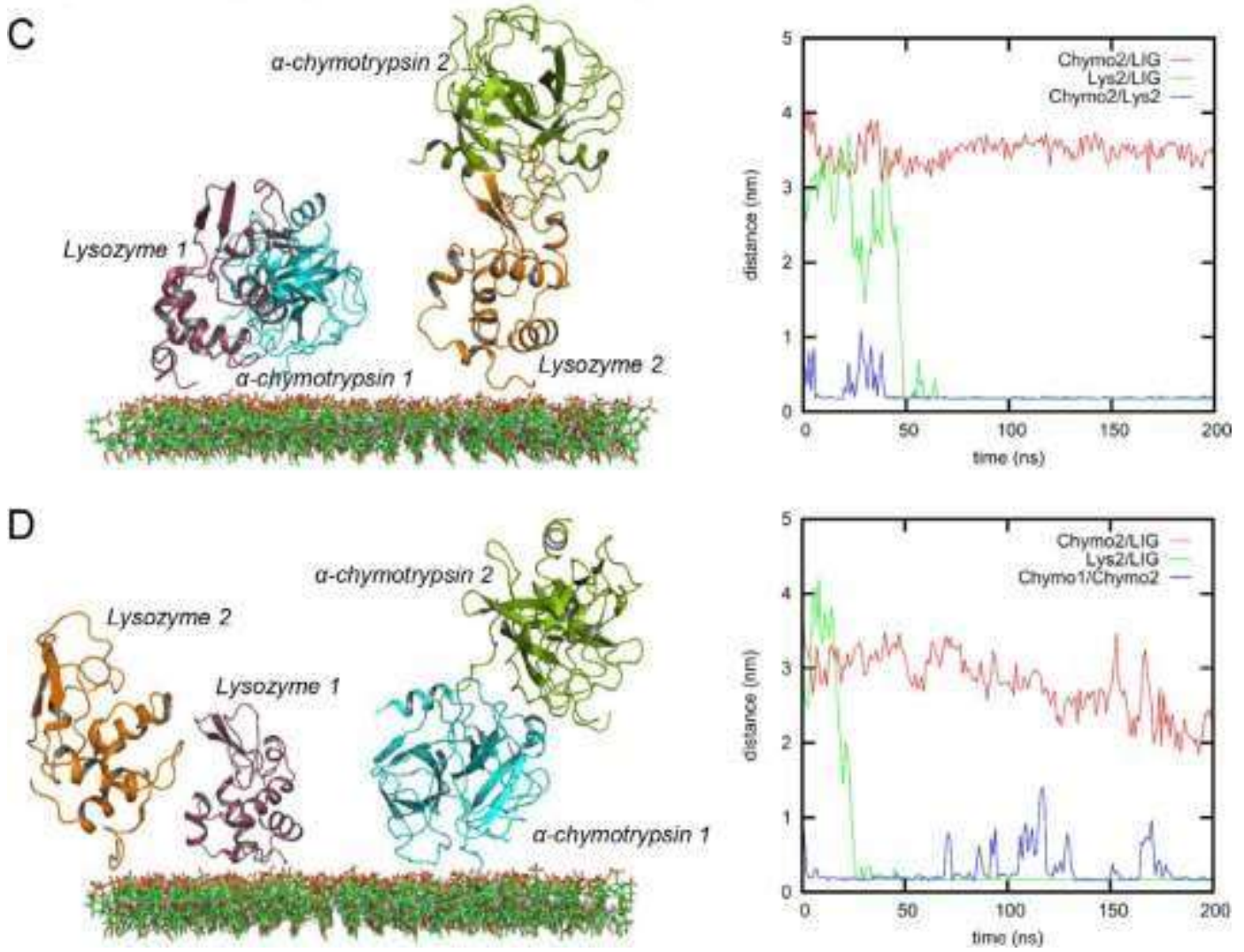

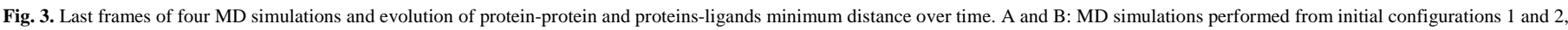
with lysozyme in red and $\alpha$-chymotrypsin in cyan. C and D: MD simulations performed from initial configuration 3 , with lysozyme in red or orange, and $\alpha$-chymotrypsin in cyan or green. 
sults are available in Supplementary Information Figures SI.2 et SI.3). Figs. 3 .A and $\mathrm{B}$, representing results from the 2-proteins con- figuration, show that both proteins were adsorbed during the sim- ulations. However, if the lysozyme was always adsorbed onto the chromatographic surface (green curves), the achymotrypsin ad- sorbed on the surface ( Figure 3 .A) and on the adsorbed lysozyme forming a multilayer ( Figure 3 .B). The evolution of minimum distances over time seems to show that $\alpha$-chymotrypsin adsorp- tion is hindered by the lysozyme electrostatic field. Indeed, when lysozyme is the first protein adsorbed, $\alpha$-chymotrypsin tends to adsorb in multilayer as suggested with the isotherms. Results corresponding to the 4-proteins configuration are presented on Figs. 3.C and D. In this situation of stronger competition be- tween proteins, $\alpha$ chymotrypsin adsorbed on other proteins ( $\alpha$ - chymotrypsin or lysozyme) during each simulation.

In both conditions, a preferential adsorption of lysozyme on the chromatographic surface is observed and could be explained by the strong distribution of positive charges on its surface. Experi- mentally, lysozyme also has more affinity with the resin that the $\alpha$-chymotrypsin. Conversely, achymotrypsin appears to be able to form a multilayer in both conditions: when the protein con- centration is relatively low (two proteins in the simulation box), and at high concentration (four proteins in the simulation box). In this case, the adsorption of the second $\alpha$-chymotrypsin on another protein could be emphasized by the limited surface area avail- able, caused by the placement of adsorbed proteins on the chro- matographic surface. The heterogeneous charge distribution of $\alpha$ - chymotrypsin, studied in paragraph 3.1, could explain its ability to interact with the positively charged surface of lysozyme and $\alpha$ - chymotrypsin. Indeed, most of $\alpha$-chymotrypsin residues in inter- action with lysozyme (see Table SI.1) are not located on the highly positively charged area on $\alpha$-chymotrypsin surface. As an example, Figure SI.4 shows electrostatic distribution of adsorbed proteins.

Finally and specially, in those situations where surface area available for adsorption is limited, MD simulations show that $\alpha$-chymotrypsin is able to form a multilayer, both with the lysozyme and with itself, which is possible due to the particular charge dis- tribution on the protein surface. These results agree with the ob- servations made at macroscopic scale.

\section{Conclusion}

MD simulations were successfully used to explore molecular mechanisms involved during simultaneous adsorption of two pro- teins, showing a good agreement with macroscopic experiments. The charge distribution on protein surface appears to be a rel- evant information to understand phenomena that are difficult to predict with empirical or semi-empirical models such as the Steric Mass Action law. Indeed, according to both macroscopic experi- ments and MD simulations, $\alpha$-chymotrypsin adsorbs as a multi- layer in competitive situation (high concentrations). Despite a pos- itive net charge in the chosen working conditions, $\alpha$-chymotrypsin shows two distinct zones at its surface, one of them predominantly negative and involved in the interaction with lysozyme, or even with another $\alpha$-chymotrypsin.

However, it is important to notice that these simulations show the appearance of a multilayer phenomenon when the proteins are already close to the surface as a first result. More simulations will be conducted to better understand these interactions, especially at low concentration. Furthermore, in order to quantify the strength of protein-protein interactions, binding energies will be calculated and compared to protein-ligands interactions.

\section{Declaration of Competing Interest}

The authors declare that they have no competing interests.

\section{CRediT authorship contribution statement}

Marine Tournois: Investigation, Writing - original draft, Methodology, Software, Formal analysis, Validation. Stéphane Mathé: Supervision, Conceptualization. Isabelle André: Project ad- ministration, Supervision, Resources. Jérémy Esque: Methodology, Software, Writing - review \& editing, Conceptualization. María A. Fernández: Project administration, Supervision, Resources, Concep- tualization.

\section{Acknowledgments}

This work was supported by the French Ministry of Higher Ed- ucation, Research and Innovation. We are grateful for its financial support. This work was granted access to the HPC resources on the TGCC-Occigen supercomputer and the Computing mesocenter of Région Midi-Pyrénées (CALMIP, Toulouse, France).

\section{Supplementary material}

Supplementary material associated with this article can be found, in the online version, at doi: 10.1016/j.chroma.2021.462151

\section{References}

[1] T.M. Przybycien, N.S. Pujar, L.M. Steele, Alternative bioseparation operations: life beyond packed-bed chromatography, Current Opinion in Biotechnology 15 (5) (2004) 469-478, doi: 10.1016/j.copbio.2004.08.008.

[2] A. Jungbauer, Continuous downstream processing of biopharmaceuticals, Trends in Biotechnology 31 (8) (2013) 479-492, doi: 10.1016/j.tibtech.2013.05. 011

[3] A.M. Lenhoff, Ion-exchange chromatography of proteins: the inside story, Ma- terials Today: Proceedings 3 (10) (2016) 3559-3567, doi: 10.1016/j.matpr.2016. 10.038

[4] R.K. Lewus, G. Carta, Binary protein adsorption on gel-composite ion-exchange media, AIChE Journal 45 (3) (1999) 512-522, doi: 10.1002/aic.690450308

[5] X. Xu, A.M. Lenhoff, Binary adsorption of globular proteins on ion-exchange media, Journal of Chromatography A 1216 (34) (2009) 6177-6195, doi: 10.1016/ j.chroma.2009.06.082 .

[6] S.R. Olsen, F.S. Watanabe, A method to determine a phosphorus adsorp- tion maximum of soils as measured by the langmuir isotherm1, Soil Sci- ence Society of America Journal 21 (2) (1957) 144, doi: 10.2136/sssaj1957. 03615995002100020004x .

[7] N.Z. Misak, Langmuir isotherm and its application in ion-exchange reactions, Reactive Polymers 21 (1-2) (1993) 53-64, doi: 10.1016/0923- 1137(93)90054- j

[8] B. Coquebert de Neuville, A. Tarafder, M. Morbidelli, Distributed pore model for biomolecule chromatography, Journal of Chromatography A 1298 (2013) 26-34, doi: 10.1016/j.chroma.2013.04.074

[9] C.A. Brooks, S.M. Cramer, Steric mass-action ion exchange: Displacement pro- files and induced salt gradients, AIChE Journal 38 (12) (1992) 1969-1978, doi: 10.1002/aic.690381212

[10] R.E. Ferner, J.K. Aronson, Cato guldberg and peter waage, the history of the law of mass action, and its relevance to clinical pharmacology, British Journal of Clinical Pharmacology 81 (1) (2015) 52-55, doi: $10.1111 /$ bcp. 12721

[11] M.V. Ernest, R.D. Whitley, Z. Ma, N.-H.L. Wang, Effects of mass action equilibria on fixedbed multicomponent ion-exchange dynamics, Industrial \& Engineer- ing Chemistry Research 36 (1) (1997) 212-226, doi: 10.1021/ie960167u

[12] J. Liang, G. Fieg, Q.-H. Shi, Y. Sun, Single and binary adsorption of proteins on ionexchange adsorbent: The effectiveness of isothermal models, Journal of Separation Science 35 (17) (2012) 2162-2173, doi: 10.10 02/jssc. 201200101

[13] H. Iyer, S. Tapper, P. Lester, B. Wolk, R. van Reis, Use of the steric mass ac- tion model in ion-exchange chromatographic process development, Journal of Chromatography A 832 (12) (1999) 1-9, doi: 10.1016/s0021-9673(98)01002-4

[14] Y. Huang, J. Bi, L. Zhao, G. Ma, Z. Su, Regulation of protein multipoint ad- sorption on ionexchange adsorbent and its application to the purification of macromolecules, Protein Expression and Purification 74 (2) (2010) 257-263, doi: 10.1016/j.pep.2010.07.002

[15] P. Trodler, J. Nieveler, M. Rusnak, R.D. Schmid, J. Pleiss, Rational design of a new one-step purification strategy for Candida antarctica lipase B by ion- exchange chromatography, Journal of Chromatography A 1179 (2) (2008) 161-167, doi: 10.1016/j.chroma.2007.11.108

[16] M. de Souza Gama, M.S. Santos, E.R. de Almeida Lima, F.W. Tavares, A.G.B. Bar- reto, A modified poisson-boltzmann equation applied to protein adsorption, Journal of Chromatography A 1531 (2018) 74-82, doi: 10.1016/j.chroma.2017.11. 022

[17] T. Briskot, T. Hahn, T. Huuk, J. Hubbuch, Adsorption of colloidal proteins in ion- exchange chromatography under consideration of charge regulation, Journal of Chromatography A 1611 (2020) 460608, doi: 10.1016/j.chroma.2019.460608

[18] T. Yang, M.C. Sundling, A.S. Freed, C.M. Breneman, S.M. Cramer, Prediction of pHdependent chromatographic behavior in ion-exchange systems, Analytical Chemistry 79 (23) (2007) 8927-8939, doi: 10.1021/ac071101j

[19] W.N. Ainis, A. Boire, V. SolJamault, A. Nicolas, S. Bouhallab, R. Ipsen, Contrast- ing assemblies of oppositely charged proteins, Langmuir 35 (30) (2019) 9923 9933, doi: 10.1021/acs.langmuir.9b01046. PMID: 31264885

[20] T.J. Dolinsky, J.E. Nielsen, J.A. McCammon, N.A. Baker, PDB2PQR: An automated pipeline for the setup of Poisson-Boltzmann electrostatics calculations, Nucleic acids research 32 (2004) W665-7, doi: 10.1093/nar/gkh381

[21] N.A. Baker, D. Sept, S. Joseph, M.J. Holst, J.A. McCammon, Electrostatics of nanosystems: Application to microtubules and the ribosome, Proceedings of the National Academy of Sciences 98 (18) (2001) 10037-10041, doi: 10.1073/ pnas.181342398

[22] E. Jurrus, D. Engel, K. Star, K. Monson, J. Brandi, L.E. Felberg, D.H. Brookes,

L. Wilson, J. Chen, K. Liles, M. Chun, P. Li, D.W. Gohara, T. Dolinsky, R. Konecny, D.R. Koes, J.E. Nielsen, T. Head-Gordon, W. Geng, R. Krasny, G.-W. Wei, M.J. Holst, J.A. McCammon, N.A. Baker, Improvements to the APBS biomolec- ular solvation software suite, Protein Science 27 (1) (2017) 112-128, doi: 10. 1002/pro.3280

[23] Schrödinger, LLC, The PyMOL Molecular Graphics System, Version 1.7, 2015. 
[24] M. Tournois, S. Mathé, I. André, J. Esque, M.A. Fernández, Understanding ad- sorption behavior of $\alpha$-chymotrypsin onto cation exchanger using all-atom molecular dynamics simulations, Journal of Chromatography A 1614 (2020) 460720, doi:

10.1016/j.chroma.2019.460720.

[25] P. Hudky, G. Kaslik, I. Venekei, L. Grf, The differential specificity of chy- motrypsin A and $\mathrm{B}$ is determined by amino acid 226, European Journal of Bio- chemistry 259 (1-2) (1999) 528-533, doi: 10.1046/j.1432-1327.1999.0 0 075.x

[26] L.R. Wetter , H.F. Deutsch , Immunological studies on egg white proteins, iv. immunochemical and physical studies of lysozyme., The Journal of biological chemistry 192 (1951) 237-242 .

[27] F. Dismer, M. Petzold, J. Hubbuch, Effects of ionic strength and mobile phase $\mathrm{pH}$ on the binding orientation of lysozyme on different ion-exchange ad- sorbents, Journal of Chromatography A 1194 (1) (2008) 11-21, doi: 10.1016/j. chroma.2007.12.085

[28] G. Carta, A. Jungbauer, Protein Chromatography, Wiley VCH Verlag GmbH, 2010 